\title{
REMUNERATION OF PUBLIC SERVANTS IN THE FEDERAL REPUBLIC OF GERMANY
}

\author{
Larysa Nalyvaiko', Galiya Chanysheva², Serhii Kozin ${ }^{3}$
}

\begin{abstract}
The aim of the article is to determine the specificities of the remuneration of civil servants in the Federal Republic of Germany. The subject of the study is the remuneration of civil servants in the Federal Republic of Germany. Methodology. The study is based on the use of general scientific and special-scientific methods and techniques of scientific knowledge. The dialectical method enabled to interrogate the development of the institution of the remuneration of civil servants in the Federal Republic of Germany. The comparative legal method enabled to compare doctrinal approaches to this issue. The system-structural method enabled to determine the elements of the remuneration of civil servants of the Federal Republic of Germany. Methods of analysis and synthesis helped study certain parts of this institute to formulate further conclusions about its most optimal functioning. The logicsemantic method was used to determine the content of the principles of "ensuring a decent standard of living for a public servant," "equality of public service actors" and "allowance/supplies". The normative-dogmatic method enabled to analyse the content of legal regulations of the domestic legislation and the legislation of the Federal Republic of Germany on the issue. Practical implications. The determination of the specificities of the remuneration of public servants in the Federal Republic of Germany enabled to make recommendations for improving the remuneration system of this category of employees in Ukraine, as well as identify problematic issues that require further consideration and research. Relevance/originality. The author's definition of the concept of "remuneration of public servants" is proposed and the specific features of this institute, insufficiently studied before, are analysed. The article analyses the specificities of the remuneration of public servants. Their list is determined and the content of each of them is disclosed. The specificities of the remuneration of public servants are substantiated in comparison with other categories of employees. The study of the positive experience of Germany enabled to suggest: to adopt a special legal regulation on the remuneration of public servants in Ukraine, that is, the Law of Ukraine "On Remuneration of Public Servants"; to provide in the norms of the Law of Ukraine "On Public Service" the allowances for the professionalism of a public servant; to provide public servants with the opportunity to carry out another paid activity subject to the special permission of the head of a state body.
\end{abstract}

Key words: remuneration, labour, public servant, Germany, labour legislation.

JEL Classification: J32, R23

\section{Introduction}

Since the proclamation of Ukraine's independence, the state policy on legal regulation of the activities of public servants has been focused on active transformations and the formation of fundamentally new mechanisms, different from those inherent in the Soviet system. The regulatory framework has been undergoing constant formation and improvement, the special legislation in this area has been adopted and repeatedly amended, the implementation of the relevant legal relationships by subjects involved has been regulated, modernization of mechanisms has been implemented, etc. In most developed countries, the public service was radically reformed in the 70-80s of the last century, and today they built a professional and high-quality public service that is an example for Ukraine. Therefore, in order to implement further reform of the public service in our state, it is important to analyse the positive foreign experience and establish areas for its use in domestic conditions.

One of these areas should be the remuneration of public servants. In the context of European integration processes in our state, the involvement of high-skilled personnel in the public service is complicated by the insufficient level of financial maintenance for public servants. The inability to compete with the private sector of the economy in terms of employment leads to demotivation on the part of the population in

\footnotetext{
Corresponding author:

${ }^{1}$ Dnipropetrovsk State University of Internal Affairs, Ukraine.

${ }^{2}$ National University “Odessa Law Academy”, Ukraine.

${ }^{3}$ National University of Life and Environmental Sciences of Ukraine, Ukraine.
} 
employment in public administration. Today, Ukraine has a number of social, economic, and political problems. Therefore, the use of purely economic instruments to address the existing problems of the remuneration of public servants is not enough at present, as a radical increase in salaries is impossible in this area. At the same time, it would be expedient to develop the remuneration system based on foreign experience, on the one hand, to satisfy the interests of employees, and on the other hand, to be within the capabilities of the state. Therefore, the scientific analysis of other countries' experience in providing the remuneration of public servants will contribute to the formation of a public service policy in Ukraine that will maximize the effectiveness of protecting the rights and interests of all working citizens of this category. The relevance of the study on this issue is verified by the current improvement of legal regulation in many spheres of domestic social life following the model of more developed countries. Therefore, it would be advisable to further reform the remuneration of public servants of Ukraine on the basis of the positive experience of other states due to the evident interrelation between the remuneration of public servants and the public service efficiency, because the latter depends on the quality of staffing of the institute.

\section{Literature review}

The topic of public service functioning in foreign countries is regularly discussed by domestic experts. It should be noted that certain issues of foreign experience of legal regulation of civil servants' performance were analysed by such scholars as: V. B. Averianov, V. D. Bakumenko, Yu. P. Bytiak, N. O. Bohdanova, V. D. Bondar, A. O. Holovachova, T. O. Horetska, S.D.Dubenko, M. I. Inshyn, Yu. Yu. Kizilov, A. V. Kirmach, Yu. V. Kovbasiuk, L. M. Kornuta, I. P. Lopushynskyi, V. Ya. Malynovskyi, O. Yu. Obolenskyi, V. P. Tymoshchuk and others. However, in the legal doctrine of our state, most works devoted to the experience of other states are purely informative. Meanwhile, tangible proposals for the implementation of foreign experience in domestic conditions are mostly not provided, which determines the expediency of such a study.

\section{Main material}

Further development of the remuneration of public servants and its meeting the European standards of legal regulation is impossible without studying and considering the experience of foreign countries. In our study, the experience of European states is highlighted that is important in the context of Ukraine's European integration. Analysing European states' experience, which is under consideration in many works of domestic scientists, the legal regulation of the remuneration of civil servants in the Federal Republic of Germany should come first. The relevance of analysing the experience of this particular state is due to the following factors:

1) as noted in scientific works, in Prussia, the professional state service was one of the first in Europe (Lopushynskyi, 2011), and hence, today it is one of the most developed;

2) the Federal Republic of Germany is one of the leading countries of the European Union, and therefore, in the context of the European integration course of Ukraine, the experience of such states is one of the top priorities for the study;

3) legal regulation of public service in the Federal Republic of Germany is widely considered in the domestic scientific literature; however, tangible proposals to improve the remuneration of public servants on the basis of German experience are absent; 4) the Federal Republic of Germany has an extensive system of legal regulations on this issue.

In Germany, since the post-war period, there is no concept of "state service" (Staatdienst), because the term "public service" (offentliches Dienst) is in practical and scientific use (Lopushynskyi, 2011). The issue of legal regulation of the activities of civil servants in the Federal Republic of Germany is provided for by several laws, but the main ones are the German Constitution of May 23, 1949 (Osnovnoi zakon Federatyvnoi Respubliki Germanii), Federal Law "On Officials (Public Servants)" as of February 27, 1985 (Pro chynovnykiv (sluzhbovtsiv)) and the special Federal Law "On Official Salaries of Public Servants" as of May 23, 1975 (Bundesbesoldungsgesetz. Ausfertigungsdatum). T.O. Horetska argues that particularly, the role of the latter should be considered because the public service system in the Federal Republic of Germany is formed on the main principle to ensure an appropriate standard of living for a civil servant (Horetska, 2009). Considering this principle is important, because in the current Law of Ukraine "On Public Service" no. 889-VIII as of December 10, 2015 (Pro derzhavnu sluzhbu), this principle is absent.

In the context of the issue under the study, in the Constitution of the FRG of May 23, 1949 (Osnovnoi zakon Federatyvnoi Respubliki Germanii), Article 33 provides for the principle of equal access to any public office. It proclaims that no one may be prejudiced because of his adherence or non-adherence to a confession, ideology or affiliation with political parties, besides managerial structures of sectors, where women are inadequately represented, give priority to equally qualified female candidates. In comparison with the provisions of the Constitution of Ukraine (Konstytutsiia Ukrainy), it should be noted that: first, in the Basic Law of our state, issues related to the public servant professional performance are regulated concerning all employees without exception, not separately; and second, the regulation of certain issues, which domestic 
scientists consider to refer to "European standards" (gender issues and issues of religion), are ensured. Therefore, in the remuneration of public servants, this principle manifests itself in establishing equal pay for all public servants, regardless of gender, religious beliefs, outlook or affiliation with political parties. At the same time, the salaries of civil servants in the Federal Republic of Germany are influenced by other factors identified by the legal regulations previously listed. In addition, in the Federal Republic of Germany, the constitutional basis for employee remuneration is the principle of maintenance: one of the basic principles of the official status while in office (Konstytutsiia Ukrainy). In fact, the state pays not for individual employee's work done but compensates for their service as a whole. Remuneration necessarily corresponds to the occupied position of the person and it ensures that civil servants are able to devote themselves entirely to their duties since only a financially independent official can selflessly work for the state (Lopushynskyi, 2011). Salaries of officials are calculated, depending on the office and on the length of time spent in the office, taking into account their age and peculiarities of the work performed, however, such issues are not regulated by the Basic Law of the Federal Republic of Germany, but by acts of special legislation.

In Germany, similarly to Ukraine, a special sectoral legal act, the Federal Law "On Officials (Civil Servants)" as of February 27, 1985 (Pro chynovnykiv (sluzhbovtsiv)), was adopted to regulate the labour rights of civil servants. In the Federal Republic of Germany, in the context of the remuneration of civil servants, the first notable feature is their possible division into two types: those who receive salaries and those who do not receive. According to I. P. Lopushynskyi, the latter include "honorary officials" who predominantly have a civilian profession and who are assigned to special positions without pay or the right to claim special social welfare provisions. Honorary officials include jurors, elected consuls, etc. (Lopushynskyi, 2011). The specificities of the calculation and determination of the rate of the remuneration of civil servants in the Federal Republic of Germany are provided for in regulations of another legal act adopted on this issue.

Therefore, primarily, the Law of the Federal Republic of Germany “The Civil Servants' Remuneration Act” as of May 23, 1975 (Bundesbesoldungsgesetz. Ausfertigungsdatum) provides for the right of civil servants to a salary. The remuneration of officials consists of the basic salary, local supplements, office allowances, as well as other additional payments that are provided for quite a lot (for example, child allowance, performance bonuses and performance allowances, special supplementary payments depending on the conditions of the labour market). All salary related issues are governed by a common legal framework and are valid for federal, county, and community officials.
According to T. O. Horetska, in the Federal Republic of Germany, on the basis of this legal act, there are four pay scales of remuneration applicable to various professional groups of civil servants: 1) civil servants pay scales $A$ and $B$ govern the remuneration of civil servants, who are members of the government, and for military personnel; 2) pay scale $\mathrm{W}$ is for professors at higher education institutions; 3 ) payscale R is for judges and public prosecutors (Horetska, 2009). Moreover, the pay scale A assigns 16 grades, B contains 11, $\mathrm{W}$ includes $3, \mathrm{R}$ has 10 grades and so on. In other words, in the Federal Republic of Germany, various factors influence calculating the rate of official salaries. To compare, it should be considered that part 2 of Article 50 of the Law of Ukraine "On Public Service” no. 889-VIII as of December 10, 2015 (Pro derzhavnu sluzhbu), determines that the salary of a public servant in Ukraine consists of: 1) a salary; 2) allowances for the length of time spent in office; 3) an allowance for the grade of a public servant; 4) recompense for additional workload due to the performance of duties of a temporarily absent public servant in the amount of 50 percent of the official salary of a temporarily absent public servant; 5) recompense for additional workload in connection with the performance of vacant position duties of public service at the expense of saving the salary fund for the corresponding position; 6) bonuses (in case of assigning). In Ukraine, the Resolution of the Cabinet of Ministers of Ukraine "Issues of Remuneration of Employees of State Bodies" no. 15 as of January 18, 2017, was adopted (The Cabinet of Ministers of Ukraine). Nevertheless, it provides for the main criterion for the differentiation of the remuneration of public servants such as the "salary group", which depends on the position of the public service (head, deputy head, expert, specialist, etc.). Therefore, legal regulation of calculating remuneration is much more detailed in the Federal Republic of Germany.

Considering allowances stipulated by the German Federal Law "On Salaries of Civil Servants" as of May 23, 1975 (Bundesbesoldungsgesetz. Ausfertigungsdatum), the family allowance should be reflected. Thus, the specified legal act establishes two levels of additional payments, which depend on the family status of civil servants. The first level is for married, widowed, divorced civil servants, who have a duty of maintenance to ex-husband/wife. The second level is for civil servants entitled to the general statutory child benefit. Other allowances related to the family status of civil servants depend directly on the number of children in the family.

T. O. Horetzka has carefully considered allowances of civil servants. The scientist highlights that after 15 years in the public service, the official salary of a civil servant ceases to increase, which prompts civil servants, who have reached the age limit for the length 
of time spent in the office, to retire or seek employment in the private sector. In this case, the amount of the bonus depends on the performance and is evaluated according to the following criteria: 1) performance (quality and usefulness, timeliness of orders execution, load, efficiency); 2) expert knowledge; 3) methods of work (level of autonomy during performance, initiative, ability to express in writing and verbally their thoughts, competencies demonstrated, orientation to the provision of services); 4) social qualities (responsibility, reliability, ability to work in a team, conflict resolution); 5) leadership (ability to organize work, instruct and coordinate, delegate authority, motivate and maintain) (Horetska, 2009). Therefore, not only subjective but also professional qualities affect the amount of the remuneration of civil servants in the Federal Republic of Germany. In this aspect, the system of bonuses in a given state is similar to Ukrainian but is considerably detailed and includes more criteria.

However, I. P. Lopushynskyi argues that in the context of the remuneration of civil servants, the most specific feature of German legislation is a secured right of civil servants to another paid activity, for example, for activities in associations, institutions, enterprises with public-owned capital, or activity in international associations. This right implementation is subject to the special permission of the head of a state body (Lopushynskyi, 2011). However, this provision seems ambiguous. On the one hand, a civil servant does not focus entirely on his direct duties and objectively cannot perform them flawlessly. On the other hand, the right to additional legal earnings removes a part of the responsibility from the state for the maintenance of public servants. That is, under the economic crisis in Ukraine, our state can allow public servants to keep themselves and their family members at their own expense. This may cause a conflict of interest between a public authority or a local government, in which a public servant' office is, and his/her other place of employment. However, in this context, it should be emphasized that in the Federal Republic of Germany a special permit from the head of a state body is necessary. That is, the law provides for control preventing intersection of the position in associations, institutions or enterprises, in which the civil servant works concurrently, with the functions of the relevant state body. Therefore, in such cases, the possibility of using the official position is minimized.

Therefore, based on the study carried out, the potential areas of using the positive experience of the Federal Republic of Germany in domestic law regarding the remuneration of public servants can be suggested:

1. On the example of the experience of the Federal Republic of Germany, it is appropriate to adopt a special legal regulation on the remuneration of public servants: the Law of Ukraine "On Remuneration of Public Servants." This will provide a much more detailed regulation to the relevant legal relationships. Regarding the structure of this legal regulation, based on the Law of the Federal Republic of Germany "On Salaries of Civil Servants" as of May 23, 1975 (Bundesbesoldungsgesetz. Ausfertigungsdatum), it will include the following sections: "general provisions", which will determine the structure of remuneration, the basic terminology in this sphere, the principles of remuneration, etc.; each subsequent section should be devoted to the specifics of remuneration of each category of public servants in accordance with the provisions of paragraph 2, Article 3 of the Law of Ukraine "On Public Service" no. 889-VIII as of December 10, 2015 (Pro derzhavnu sluzhbu). The regulation of specific allowances should be under special legislative consideration. In particular, based on the experience of Germany, such allowances can be family ones, depending on the marital status or the number of children. The rate of official salaries is expedient to regulate by law because they are constantly changing due to an unstable national economy.

2. To provide for in the Law of Ukraine "On Public Service" no. 889-VIII as of December 10, 2015 (Pro derzhavnu sluzhbu), public servant performance bonuses. In order to implement this, part 2 of Article 50 of this legal regulation should be amended by adding another sub-clause:

"The salary of a public servant consists of:

... 7) performance bonuses.”

Moreover, in this context, article 52 should be added with another part of the following content:

"...The performance bonus is established by the head of a public service to public servant upon the submission of his/her direct supervisor according to the following criteria: professional performance; expert knowledge; methods of work; social quality; leadership."

3. Since the economic situation in Ukraine is unsatisfactory today, in the Law of Ukraine "On Public Service" no. 889-VIII as of December 10, 2015 (Pro derzhavnu sluzhbu), it is quite reasonable to provide public servants with the possibility to carry out another paid activity subject to the special permission of the head of a state body.

For this, Section II "Legal status of a public servant" of this legal regulation should be added with the article "The right to another paid activity" as follows:

"Article ... The right to another paid activity.

1. A public servant has the right to another paid activity that will not have a negative impact on the image of the state body and trust in the authorities and will not endanger the constitutional order, territorial integrity and national security, for the health and rights and freedoms of other people.

2. Permission for another paid activity is provided for by the head of the public service by issuing an order". 


\section{Conclusions}

Therefore, the model of the remuneration of civil servants in the Federal Republic of Germany is similar to the Ukrainian one. Significant differences involve much more perfect regulation of issues related to salaries of civil servants, a much more developed system of allowances to the basic salary, as well as the adoption of a special legal act devoted exclusively to the issue of the remuneration of civil servants. Therefore, in general, the domestic institution of the remuneration of public servants is currently regulated at a fairly decent level, and potential ways of improvement should be focused on the detailing of existing provisions. The following features of the remuneration of civil servants in the Federal Republic of Germany should be distinguished: 1) the adoption of a special legal act, the Federal Law "On Salaries of Civil Servants" as of May 23, 1975 ; 2) a special category of civil servants who do not receive salaries at all; 3 ) the ability of civil servants to carry out another paid activity; 4) the right of civil servants to more allowances to the basic salary.

\section{References:}

Lopushynskyi, I. P. (2011). Publichna sluzhba Nimechchyny: dosvid dlia Ukrayiny [Public service of Germany: experience for Ukraine]. Derzhavna sluzhba, 4, 48-54. (in Ukrainian)

Osnovnoi zakon Federatynnoi Respubliki Germanii [The basic Law of the Federal Republic of Germany] (May 23, 1949). Retrieved from: https://yurist-online.org/laws/foreign/const_germany/_doc.pdf

Pro chynovnykiv (sluzhbovtsiv) [On officials (civil servants)] (Federal Law of February 27, 1985). Retrieved from: http://www.bundestag.de/

Bundesbesoldungsgesetz. Ausfertigungsdatum: 23.05.1975 [The Federal Pay Act of May 23, 1975]. Retrieved from: https://www.gesetze-im-internet.de/bbesg/BJNR011740975.html

Horetska, T. (2009). Systema oplaty pratsi derzhavnykh sluzhbovtsiv u yevropeiskykh krainakh [The system of remuneration of civil servants in European countries]. Zbirnyk naukovykh prats Natsionalnoi akademii derzhavnoho upravlinnia pry Prezydentovi Ukrainy, 1, 43-51. (in Ukrainian)

Pro derzhavnu sluzhbu [On Public Service] (The Law of Ukraine no. 889-VIII of December 10, 2015). Vidomosti Verkhovnoi Rady Ukrainy, 4, Art. 43. (2016). (in Ukrainian)

Konstytutsiia Ukrainy [The Constitution of Ukraine] (Law of Ukraine no. 254k / 96-VR of 28 June 1996). Vidomosti Verkhovnoi Rady Ukrainy, 30, Art. 141. (2016). (in Ukrainian)

The Cabinet of Ministers of Ukraine. Pytannia oplaty pratsi pratsivnykiv derzhavnykh orhaniv [Issues of remuneration of employees of state bodies]. (Resolution no. 15 of January 18, 2017). Retrieved from: https://www.kmu.gov.ua/ua/npas/249668347 (in Ukrainian) 